\title{
Qualified Person Identifier
}

National Cancer Institute

\section{Source}

National Cancer Institute. Qualified Person Identifier. NCI Thesaurus. Code C94034.

A unique symbol that establishes identity of the qualified person. 